\title{
Fuel Efficiency Vehicle Adoption and Carbon Emissions in a Country Context
}

\author{
Juliet Namukasa \\ Department of Procurement and Logistics Management \\ Makerere University Business School \\ E-mail: jnamukasa@mubs.ac.ug \\ Sheila Namagembe \\ Department of Procurement and Logistics Management \\ Makerere University Business School \\ E-mail: snamagembe@mubs.ac.ug \\ Faridah Nakayima \\ Department of Procurement and Logistics Management \\ Makerere University Business School \\ E-mail: fnakayima@mubs.ac.ug
}

Received: November 12, 2019 Accepted: January 7, 2020 Published: January 11, 2020

doi:10.5296/ijgs.v4i1.16227

URL: https://doi.org/10.5296/ijgs.v4i1.16227

\begin{abstract}
The paper aimed at establishing the relationship between age, engine capacity, fuel type and fuel efficiency and carbon emissions. The relationship was obtained using panel data on newly imported registered vehicle stock obtained from Uganda Revenue Authority. This involved collecting data on imported vehicle inventory into Uganda for the period from 2013 to 2017 which was later analysed using the stata software. The findings indicated a positive relationship between a vehicles age, engine capacity, vehicle category (Light Duty Vehicles, Medium Duty Vehicles and Heavy Duty Vehicles) and fuel efficiency and carbon emissions.
\end{abstract}


A comparison with the global fuel efficiency targets indicated that more fuel was being consumed in Uganda compared to non-OECD countries. A reduction in fuel consumption and emissions was observed in petrol vehicles while diesel vehicles had increased carbon emissions and fuel consumptions due to an increase in engine capacities. The findings imply that government should develop policy options that promote vehicle fuel efficiency, transport system operators may undergo training in fuel efficiency issues that will result in an attitudinal change while academicians need to carry out more research comparing the effect of transport systems operators ages, level education and income on carbon emissions and fuel efficiency. The majority of research on fuel efficiency and carbon emissions uses survey data rather than panel data. Further, previous research is focused on vehicles that are already on the road rather than focusing on the effect of age, engine capacity, fuel type on fuel efficiency and carbon emissions.

Keywords: Fuel efficiency, Vehicles, Carbon emissions, Energy

\section{Introduction}

Fuel efficiency of vehicles is a subject that has attracted attention of many researchers. Much of the research and emphasis on fuel efficiency is in developed nations and in varied topical areas that include fuel efficiency and motor vehicle travel (Small \& Van Dender, 2007); determinants of consumer interest in fuel economy (Popp, Van de Velde, Vickery, Van Huylenbroeck, Verbeke, \& Dixon, 2009); determinants of changes in car fuel efficiency in Great Britain (Kwon, 2006); fuel economy standards and automobile safety (Crandall \& Graham, 1989) and modelling the effects of transport policy levers on fuel efficiency and national fuel consumption (Kirby, Hutton, McQuaid, Raeside, \& Zhang, 2000). Much of the emphasis is placed on fuel efficiency rather than carbon emissions.

Carbon emissions are increasing, particularly in the developing world, where the use of vehicles is on the rise. The global vehicle fleet is set to increase rapidly from about 850 million today to as much as 2.5 to 3 billion by 2050 (Global Fuel Economy Initiative (GFEI), 2016). Ninety percent of this growth is set to take place in developing and transitional countries (Global Fuel Efficiency initiative -State-of-the-World-report, 2016). As the average vehicle fuel economy in these countries is stagnant, it is predicted that greenhouse gas emissions of the global fleet are set to triple. According to the International Energy Agency (IEA)(2013), the transport sector has the highest growth of $\mathrm{CO}_{2}$ emission of any sector. In the same perspective, Song et al. (2013) also indicate that road transportation is a major fuel consumer and greenhouse gas emitter. It's contribution to energy related $\mathrm{CO}_{2}$ emissions are estimated to go from one quarter today to one-third by 2050. Black carbon and pollutant emissions are also set to increase similarly with major health and short-term climate impacts.

Fuel economy standards have mostly been implemented in the developed (OECD) countries such as the US, Canada, Japan the EU, the BRICS (Brazil, Russia, India, China and South Africa), and a few other emerging economies. Only Mauritius has developed and implemented the first fuel economy / $\mathrm{CO}_{2}$ based fee-bate system in the developing world (Global Fuel Efficiency Initiative (GFEI), 2014). However, through the GFEI, more countries are acknowledging the need for strong policies on fuel efficiency (GFEI, 2014).

Mixed research exists on carbon emissions and fuel efficiency. The majority of these studies 


\section{MInstitute Macrothink $^{\text {Int }}$}

are scattered, characterised with conflicting findings and conducted in the developed world (see Musti \& Kockelman, 2011; Fingerman, Sheppard, \& Harris, 2018) and different industrial sectors such as the fishery industry (Parker et al., 2018). Existing research focuses on tax reforms (Parker et al., 2018); use of hybrid and electric vehicles (Fernández, 2018); blending hydrogen with natural gas to vehicles with fuel cells (Ogden, Jaffe, Scheitrum, McDonald, \& Miller, 2018) and a dearth of research on policy. Further, existing research on policy is characterised by conflicting findings. For example, Shaw, Hales, Edwards, Howden-Chapman \& Stanley (2018) found no relation between fuel tax and a reduction in gas emissions while Sterner (2007), Samaras \& Meisterling (2008) and Morrow, Gallagher, Collantes \& Lee(2010) found a positive relationship between the two aspects. Also Shaw et al. (2018) saw an increase in fuel prices as a short term solution to reducing carbon emissions.

Whereas the majority of the research has been carried out in the road transport sector (see Alam, Hyde, Duffy, \& McNabola, 2018; Fingerman et al., 2018), emphasis was placed on light duty passenger vehicles and electric vehicles (see Ahn, Rakha, Trani, \& Van Aerde, 2002; DeMelo et al., 2018). Although recent studies advise that electric vehicles may solve emission problems, Fernández (2018) found out that electric cars pollute the environment during their production at power plant level and during the generation of electricity to be stored in the batteries of these electric cars. However, transport emissions may be reduced through generating electricity using renewable energy sources such as wind, solar, geothermal and a change in social habits.

Over $50 \%$ of oil use around the world is for transport and nearly all the recent and future expected growth in oil use comes from increased transport activities. Globally, the transport sector is rising faster than any other sector and the number of vehicles on the planet is set to triple by 2050 (GFEI, 2012, 2014 and 2015a, b). Due to the rapid growth in vehicle population, especially private passenger vehicles, controlling the fuel energy demand and greenhouse gas (GHG) emissions has become a global concern (Feng et al., 2011). Thus, promoting fuel efficiency and reducing carbon dioxide $\left(\mathrm{CO}_{2}\right)$ emissions is a key global development agenda.

In Uganda, vehicle emissions are a major contributor to poor air quality particularly in urban and rural areas due to increased importation of used vehicles (Mutenyo et al., 2015), the number of hours spent in traffic, and the nature of fuel consumed among others. Given these trends, solutions are needed to reduce emissions and energy consumption from the transportation sector since it is widely believed to be a major contributor to climatic change. Good climatic change is one of the pre-requisites for poverty eradication and increased agricultural production (Hertel \& Rosch, 2010; Sanchez, 2000). In developing countries such as Uganda, agriculture is a major occupational sector and primary source of income for the poor where $70 \%$ of the population depends on agriculture. The productivity of this sector highly depends on good climate (Afedraru, 2015). Hence implementing the GFEI is a civil obligation as well as a development concern. Given the above, the paper aims at establishing the relationship between age, engine capacity, fuel type and fuel efficiency and carbon emissions using panel data of newly imported registered vehicle stock.

\section{Literature Review}

This section provides a review of both the conceptual and empirical literature on vehicle fuel 
efficiency and environmental emissions, the relationship between the age of a vehicle, engine capacity and fuel efficiency and the relationship between age of the vehicle, engine capacity, fuel type and carbon emissions.

\subsection{Vehicle Fuel Efficiency and Environmental Emissions}

Road transportation is a major fuel consumer and greenhouse gas emitter (Song, Zhang, Sekimoto, Horanont, Ueyama, \& Shibasaki, 2013). Sustaining a clean environment has become an important issue in society. Environmental emissions caused by automobiles and motorcycles are some of the relevant environmental problems to be tackled (Hsieha et al., 2002). Thus reducing pollution from motor vehicles is of great importance to mitigating climate change. Environmental emissions are considered to be proportional to the fuel consumed during vehicle's operations (Fontaras, Zacharof, \& Ciuffo, 2017). Fuel consumption is the reciprocal of fuel Efficiency and may be defined as the amount of fuel used per unit distance (Mathew, 2014). The lower the value of fuel consumption, the more economical the vehicle is said to be. Although a substantial amount of research exists on environmental emissions produced by transport systems, factors such as driving behaviour, vehicle configuration and traffic conditions are reconfirmed as highly influential (Van Mierlo, Maggetto, Van de Burgwal, \& Gense, 2004; Rakha \& Ding, 2003; Fontaras et al., 2017). Neglected factors such as side winds, rain and road grade may have significant contributions in fuel consumption in real world driving (see Fontaras et al., 2017). Fuel efficiency of a vehicle is determined by a number of factors that include vehicle characteristics, environmental and traffic conditions, and driver and user related factors.

Vehicle characteristics identified include an increase in mass weight of a vehicle (Pagerit, Sharer \& Rousseau, 2006; Wohlecker, Johannaber, \& Espig, 2007; Bishop, Martin, \& Boies, 2014); a vehicle's aerodynamic resistance(see Hucho \& Sovran,1993; Wohlecker et al., 2007); rolling resistance of a tyre (Crolla, 2009); and auxiliary systems of a vehicle for example, the air conditioning system and lights(Tong et al., 2000; Schipper, 2008; Weilenmann, Alvarez \& Keller, 2010). Environmental and traffic conditions include weather conditions (Karlsson \& Ellen, 2012); ambient temperature (Alvarez \& Weilenmann, 2012; Fontaras \& Dilara, 2012); cold start of a vehicle(Mock, German, Bandivadekar, \& Riemersma, 2012; Joumard, Andre, Laurikko, Le Anh, Geivanidis, \& Samaras, 2006; Dardiotis, Martini, Marotta, \& Manfredi 2013); road morphology, road surface and road shape (Boriboonsomsin \& Barth, 2009; Ardekani \& Sumitsawan, 2010); and traffic conditions and congestion (Burgess \& Choi, 2003; Spalding, 2008; Smit et al., 2008). Driver and user related factors involve driving behaviour of the drivers (Ericsson, 2001; Brundell-Freij \& Ericsson, 2005); aggressive driving (André \& Pronello,1997; Ericsson, 2001; Rakha \& Ding, 2003); driver training (Beusen et al., 2009; Barkenbus, 2009); eco-driving (European Environmental Agency, 2016; Joumard et al., 2006; Haworth, 2001); four-wheel drive (Fontaras, et al., 2017); and occupancy rates (Fontaras et al., 2017).

Whereas the literature may indicate the existence of the link between vehicle fuel efficiency and environmental emissions, the influence of vehicle fuel efficiency on environmental emissions has not been given significant attention in the literature. However, a reduction in environmental emissions may be achieved as a result of promoting the adoption of fuel 
efficiency vehicles among motorist owners. Although studies on vehicle fuel efficiency exist, the majority of the studies are carried in developed nations and a few developing nations with limited emphasis on African countries.

\subsection{Age of a Vehicle, Engine Capacity and Fuel Efficiency}

Fuel efficiency is a measure of how far a vehicle will travel with a gallon of fuel; it is expressed in miles per gallon while fuel consumption is the inverse of fuel economy (Greene, 2008). It is the amount of fuel consumed in driving a given distance and is measured in gallons per 100 miles, and in liters per 100 kilometers. The amount of fuel consumed depends on the engine, the type of fuel used, and the efficiency with which the output of the engine is transmitted to the wheels.

Research on vehicle's age shows that older vehicles may consume much fuel compared to new vehicles. Further, people who drive older vehicles cannot afford newer vehicles and accept lower fuel economy as a tradeoff. Other people, instead, may value lowering their fuel costs via increased new-vehicle fuel economy at the potential cost of higher vehicle investment (Popp et al., 2009). However, an improvement in fuel efficiency in a country's economy may improve when newer vehicles are bought and older vehicles are scrapped. Although fuel efficiency may improve with the purchase of new vehicles, the improvement will be more quickly observed if the average engine size is also reduced (Wang, McGlinchy, Badger \& Wheaton, 2015). A car's engine size, also known as the engine capacity or simply $\mathrm{CC}$, is the size of the volume swept by each of the cylinders, which inside combine and burn air and fuel to generate energy. The larger the engine size, the more fuel your vehicle consumes (Leduc, Dubar, Ranini, \& Monnier, 2003), the more power it produces, and the more your car accelerates. Further, the decrease of engine capacity and the increase of the specific performance helps to reduce fuel consumption by limiting pumping, friction and heat energy losses (Salamon, McAllister, Robinson, Richardson, Martinez-Botas, Romagnoli, Colin Copeland, \& Turner, 2012). However, in some cases a large sized engine may not consume more in fuel than a small sized engine, but not all the time. There are many factors that go into a vehicles' design that can have negative or positive impacts on this specific cost. For example: Engine efficiencies may be improved due to better fuels, and if refineries are able to provide the fuels demanded by modern engines at a lower cost. Thus, the potential for fuel efficiency improvement may depend on fuel attributes as well as on engine technology. Implementing certain engine technologies may require changes in fuel properties, and vice versa (Greene, 2008).

\subsection{Age of the Vehicle, Engine Capacity, Fuel Type and Carbon Emissions}

Older vehicles produce substantially more pollution than new ones and the effects become more stronger with the vehicles age (Harrington, 1997). But conflicting research findings exist whether new vehicles produce carbon emissions or not. For example, research conducted by European Environment Agency (EEA) (2018) on new vehicles shows that the average carbon dioxide $\left(\mathrm{CO}_{2}\right)$ emissions from new passenger cars and vans registered in the European Union (EU) in 2018 increased for the second consecutive year, reaching 120.4 grammes of $\mathrm{CO}_{2}$ per kilometre.

Older vehicles are being driven by poor people in developed nations and by arrange of people 
in developing countries. An older vehicle fleet in conjunction with poor maintenance practices and limited vehicle testing can mean that the impacts of motorisation on developing nations are many times worse than an equal level of motorisation in a developed nation (Wright, 2004; Fomunung, Washington, \& Guensler, 1999). Further, carbon emissions are high in older technology or tampered vehicles (Fomunung et al., 1999). However, emissions from older vehicles can be reduced through strengthening the existing inspection and maintenance programs, which require periodic emission control tests before vehicles can be reregistered. Although important, many developing countries lack inspection and maintenance program policies. Thus a reason for higher levels of carbon emissions arising from the transport industry. Also Chiang, Tsai, Yao \& Ho's (2008) findings show that emission tests before and after repair and maintenance on older vehicles fail to reduce emissions because of deterioration of the three-way catalyst over time. Besides, the age of the vehicles, carbon emissions may arise from the type of fuel used.

Fuel is not equal to fuel when carbon dioxide emissions for each are considered. Given that the majority of vehicles either use petroleum or diesel, vehicles that use diesel are found to be higher environmental emitters. Although diesel contains more carbon than petrol, carbon dioxide $\left(\mathrm{CO}_{2}\right)$ emissions of diesels tend to be lower. However, diesel cars emit significantly higher levels of other air pollutants, especially nitrogen oxides (NOx) and particulates thus affecting their environmental soundness (Organisation for Economic Co-operation and Development (OECD), 2014). Whereas petrol is seen to produce more carbondioxide than diesiel, emissions from petrol cars have been dramatically reduced by the introduction of catalytic converters, which oxidise pollutants such as $\mathrm{CO}$ to less harmful gases such as carbon monoxide (May, 2017; Bromberg, Cohn, Rabinovich, \& Heywood, 2001; Rajesh, Sundaram, Sivaganesan, Nagarajan, \& Harikishore, 2019). When compared to petrol cars without catalysts, catalyst cars have much lower $\mathrm{CO}, \mathrm{HC}$ and $\mathrm{NOx}$ emissions, at the expense of $\mathrm{CO}_{2}$ emissions, which increase due to the oxidation of carbon monoxide to $\mathrm{CO}_{2}$. As a consequence of this, a catalyst car will also use slightly more fuel and become less efficient. However, despite these improvements, petrol cars with catalysts still produce more $\mathrm{CO}$ and $\mathrm{HC}$ than diesel cars, although exhaust emissions of NOx and particulates are much lower than diesel cars. In fact particulate emissions from petrol cars are so low that they are not routinely measured. Although alternative fuels such as compressed natural gas (CNG); liquefied petroleum gas (LPG); city diesel; hydrogen; alcohol fuels; and battery operated vehicles have been developed to replace petrol and diesel, it is cheaper to improve conventional fuels(petrol and diesel) than to use many of the alternatives as no investment is needed for new storage tanks and service stations (Demirbas, 2003; Niculescu, Clenci, \& Iorga-Siman, 2019).

All in all and despite the much debate over which car, petrol or diesel, is cleaner, weighing up the advantages and disadvantages is not easy. For example, diesel cars have been promoted, as they produce less $\mathrm{CO}$ and $\mathrm{HC}$ on average when compared to petrol cars, and they have greater fuel economy producing less $\mathrm{CO}_{2}$ per km. However, recent health concerns about particulate matter have given diesels a less environmentally-friendly image, as have the higher emissions of nitrogen oxides compared with petrol cars. As a comparison, petrol cars produce virtually no particulate matter, take longer to warm up, produce more carbon dioxide per mile on average, and emissions of the regulated pollutants are higher. 


\section{Research Methodology}

Panel Data on imported vehicle inventory into Uganda for the period from 2013 to 2017 was obtained from Uganda Revenue Authority. Average fuel consumption per one kilometer, average fuel efficiency (estimated in Liters per100 Kilometers) and $\mathrm{CO}_{2}$ emission grams of carbon dioxide emissions per kilometer $\left(\mathrm{gCO}_{2} / \mathrm{Km}\right)$ were computed for vehicles registered in 2013-2017.

Fuel efficiency and carbon-dioxide emissions computations where calculated as follows: Average fuel efficiency was estimated in liters per hundred kilometers $(\mathrm{L} / 100 \mathrm{Km})$. Vehicle fuel economy was expressed in terms of liters of gasoline per 100 kilometers of travel $(\mathrm{L} / 100 \mathrm{~km})$. The vehicle fuel economy ratios were computed by fuel type and engine capacity. The vehicle database reports data on engine capacity in cubic centimeter (CC), therefore we used CC displacement for analysis. The engine capacity were categorized into 5 sub-groups $<1000,1001-1500,1501-2000,2001-2500$ and SUV (luxury cars). This was guided by an analysis made on the data. Observations from the data showed that with the exception of SUVs, the majority of the vehicles had engine capacities ranging between 1000CC and $2500 \mathrm{CCs}$. Vehicles within the same engine capacity ranges were assumed to exhibit similar fuel efficiency and $\mathrm{CO}_{2}$ emission rates and therefore comparable for the required computations. $\mathrm{CO}_{2}$ emission grams of carbon dioxide emissions per kilometre $\left(\mathrm{gCO}_{2} / \mathrm{Km}\right)$ were computed for vehicles registered in 2013-2017.

Estimates to compute $\mathrm{CO}_{2}$ emission for particular vehicle categories $\left(\mathrm{gCO}_{2} / \mathrm{km}\right)$ were derived from fuel efficiency (FE) i.e. for petrol fleet $\mathrm{CO} 2=23.2^{*} \mathrm{FE}$ of the petrol fleet while for diesel fleet $\mathrm{CO} 2=26.5^{*} \mathrm{FE}$ for diesel fleet ${ }^{1} \mathrm{FE}$ was derived from the manufacturers' websites and vehicle characteristics web portals ${ }^{2}$ Comparisons of the results on fuel efficiency with the global fuel efficiency targets were made to tell the levels of fuel consumption in Uganda in relation to the non-OECD countries.

After deriving the estimates for fuel efficiency and carbon emissions, data was analysed using the Stata software. The data on excel worksheets was imported into Stata 13 statistical software. The name Stata is a syllabic abbreviation of the words statistics and data (Jimenez-Valdivia, Malpartida-Carrillo, Rodríguez-Cárdenas, Dias-Da Silveira, \& Arriola-Guillén, 2019). Stata is a general-purpose statistical software package created in 1985 by Stata Corp. It's mostly used in research, especially in the field of economics, sociology, political science, biomedicine and epidemiology. Stata's capabilities include data management, statistical analysis, graphics, simulations, regression, and custom programming (Jimenez-Valdivia et al., 2019; Buchmann \& Downs, 2018).

\section{Results}

This section provides findings on carbon emissions and fuel efficiency. Results include the types and age of registered vehicles based on vehicle weights; Age, Engine Capacity, Fleet fuel type and Fuel efficiency; LDVs Fuel type, Engine capacities and Fuel Efficiency; and Fleet fuel type and Carbon emissions.

\footnotetext{
${ }^{1}$ Source: https://www.unitjuggler.com/convert-fuelconsumption-from-gperkmgasoline-to-lper100km.html

${ }^{2}$ http://carfueldata.direct.gov.uk/; https://www.greenvehicleguide.gov.au/;

http://www.nextgreencar.com/; https://car-emissions.com
} 


\subsection{Types of Registered Vehicles Based on Vehicle Weights}

Findings show that between 2013 and 2017, about 201732 vehicles where registered; 8.4\% fell in the category of HDVS (heavy duty vehicles), $80.1 \%$ fell in the category of LDVS(low duty vehicles) while $11.5 \%$ fell in the category of MDVS(medium duty vehicles). Analysis of the trend of vehicle registrations on average except for MDVS which registered 5541 showed that registrations were highest in 2014 for all vehicle categories (See Table 1).

Table 1. Vehicle Inventory by weight category at Registration: 2013-2017

\begin{tabular}{|c|c|c|c|c|c|c|c|}
\hline \multicolumn{8}{|c|}{ Weight category } \\
\hline \multicolumn{2}{|l|}{ Years } & \multicolumn{2}{|c|}{ HDV } & \multicolumn{2}{|c|}{ LDV } & MDV & Total \\
\hline 2013 & 4523 & $11.1 \%$ & 31977 & $78.8 \%$ & 4066 & $10.0 \%$ & 40566 \\
\hline 2014 & 6615 & $11.9 \%$ & 43909 & $79.0 \%$ & 5083 & $9.1 \%$ & 55607 \\
\hline 2015 & 2193 & $5.9 \%$ & 31336 & $83.6 \%$ & 3943 & $10.5 \%$ & 37472 \\
\hline 2016 & 2146 & $6.3 \%$ & 27317 & $80.5 \%$ & 4491 & $13.2 \%$ & 33954 \\
\hline 2017 & 1462 & $4.3 \%$ & 27130 & $79.5 \%$ & 5541 & $16.2 \%$ & 34133 \\
\hline Total & 16939 & $8.4 \%$ & 161669 & $80.1 \%$ & 23124 & $11.5 \%$ & 201732 \\
\hline
\end{tabular}

Source: Computations based on vehicle registration data for the period 2013-2017.

\subsection{Age of Registered Vehicles Based on Vehicle Weights}

Findings show that the average age of imported vehicles has been increasing over time. However, HDVs dominate the oldest fleet registered in Uganda at registration followed by MDVs and then the LDVs. LDV fleet registered averaged at 15 years at registration unlike HDV and MDV which ranged in over 20 years. The weighted average relatively increased from 15 years to 17 years between 2013 and 2017 (see Table 2). New vehicle registrations comprised the smallest proportion across vehicle weights, 5.2\%, 2.8\% and 1\% for HDV, LDV and MDV fleet respectively (see Table 3). The results indicate that Uganda imports older vehicles than new vehicles. The implication is that older vehicles were brought into the country and this signifies an increase in emission levels.

Whereas the government emphasizes the importation of new vehicles, the technology that curbs emissions in vehicles has not drastically changed with fundamentals such as how catalytic converters work for 2005, 2012 and 2018 vehicles Models (Ziraba, 2018). This is contrary to findings by Harrington (1997) and the Uganda Baseline fuel efficiency survey (2015) that show that age of a vehicle affects fuel efficiency. Thus placing more emphasis on proper maintenance, use of genuine fuels and oils and avoidance of bad driving habits may promote fuel efficiency and reduce carbon emissions. 
Table 2. Age and vehicle weight category

\begin{tabular}{lllll}
\hline Year & HDV & LDV & MDV & Overall average \\
\hline 2013 & 20 & 14 & 18 & 15 \\
2014 & 22 & 15 & 20 & 16 \\
2015 & 23 & 14 & 22 & 16 \\
2016 & 24 & 15 & 23 & 16 \\
2017 & 25 & 15 & 23 & 17 \\
\hline
\end{tabular}

Source: Computations based on vehicle registration data for the period 2013-2017.

Table 3. New versus old fleet

\begin{tabular}{llllllllll}
\hline \multicolumn{3}{c}{ Vehicle Weights } \\
Year of & HDV & \multicolumn{3}{c}{ LDV } \\
Registration & New & Old & \% of new & New & Old & \% of new & New & Old & \% of new \\
\hline 2013 & 354 & 4169 & 7.8 & 1407 & 30570 & 4.4 & 111 & 3955 & 2.7 \\
2014 & 429 & 6186 & 6.5 & 1615 & 42294 & 3.7 & 73 & 5010 & 1.4 \\
2015 & 93 & 2100 & 4.2 & 768 & 30568 & 2.5 & 31 & 3912 & 0.8 \\
2016 & & 2146 & 0.0 & 463 & 26854 & 1.7 & 17 & 4474 & 0.4 \\
2017 & & 1462 & 0.0 & 275 & 26855 & 1.0 & 5 & 5536 & 0.1 \\
Total & $\mathbf{8 7 6}$ & $\mathbf{1 6 0 6 3}$ & $\mathbf{5 . 2}$ & $\mathbf{4 5 2 8}$ & $\mathbf{1 5 7 1 4 1}$ & $\mathbf{2 . 8}$ & $\mathbf{2 3 7}$ & $\mathbf{2 2 8 8 7}$ & $\mathbf{1 . 0}$ \\
\hline
\end{tabular}

Source: Computations based on vehicle registration data for the period 2013-2017.

\subsection{Comparison Criteria for the New and Old Vehicles}

The comparison for the vehicles whether new or old were based on the year of manufacture for the vehicles. After the year of manufacture, the year of registration of the vehicle by Uganda Revenue Authority was also considered. The time lag between the year of manufacture and the year of registration was used to tell whether the vehicle was old or new. Whereas the government emphasizes the importation of new vehicles, the technology that curbs emissions in vehicles has not drastically changed with fundamentals such as how catalytic converters work for 2005, 2012 and 2018 vehicles Models (Ziraba, 2018). This is contrary to findings by Harrington (1997) and Mutenyo, Banga, Matovu, Kimera \& Lawerence (2015) that show that age of a vehicle affects fuel efficiency. Thus placing more emphasis on proper maintenance, use of genuine fuels and oils and avoidance of bad driving habits may promote fuel efficiency and reduce carbon emissions.

4.4 Age, Engine Capacity, Fleet Fuel Type and Fuel Efficiency

Findings show that diesel vehicles below 1001CC were imported while very old and the number of imported vehicles increased from 17.8-20.7 years (see Figure 1). Diesel vehicles in the categories 2001-2500CC and SUVs were relatively newer at registration compared to 


\section{Macrothink}

other categories. The average ages for the SUVs ranged from 9.4 years to13.8 years while vehicles with engine capacities of $2001 \mathrm{CC}-2500 \mathrm{CC}$ had their average ages ranging from 12 years to 15.4 years between 2013 and 2017. The average age of the diesel fleet was below15 years. Similarly for Petrol fleet, vehicles with engine capacities of 2001CC-2500CC and SUV categories were registered newer than other fleet categories. And vehicle fleet of less than $1001 \mathrm{CC}$ were oldest at registration over the period 2013-2017 (see Figure 2).

Further, Diesel registered fleet and SUVs were fuel guzzlers whose fuel consumption increased from $9.7 \mathrm{~L} / 100 \mathrm{~km}$ in 2013 to $10.7 \mathrm{~L} / 100 \mathrm{~km}$ implying a $9.3 \%$ in fuel demand to cover same distance(see Figure 3) while in the case of the petrol fleet, for the petrol fleet, SUVs average fuel consumption increased from $12.1 \mathrm{~L} / 100 \mathrm{~km}$ in 2013 to $13 \mathrm{~L} / 100 \mathrm{~km}$ implying a 6.9\% in demand for gasoline (petrol) between fleet registered in 2013 and 2017 (see Figure 4).

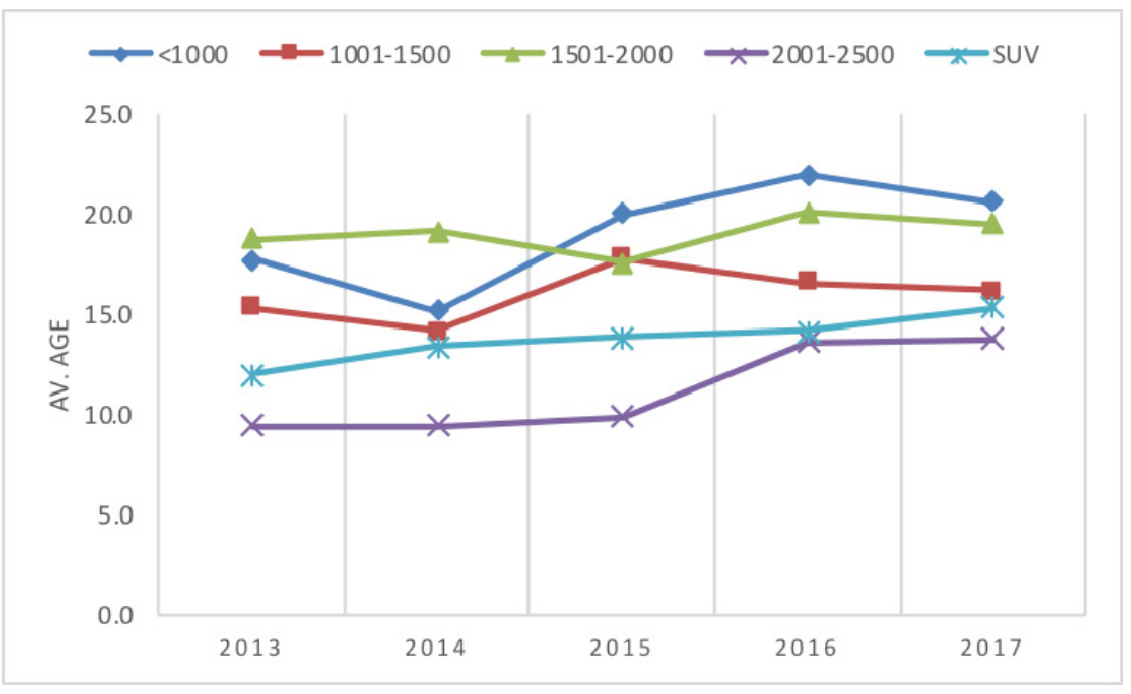

Figure 1. Age and engine capacity category for the diesel fleet

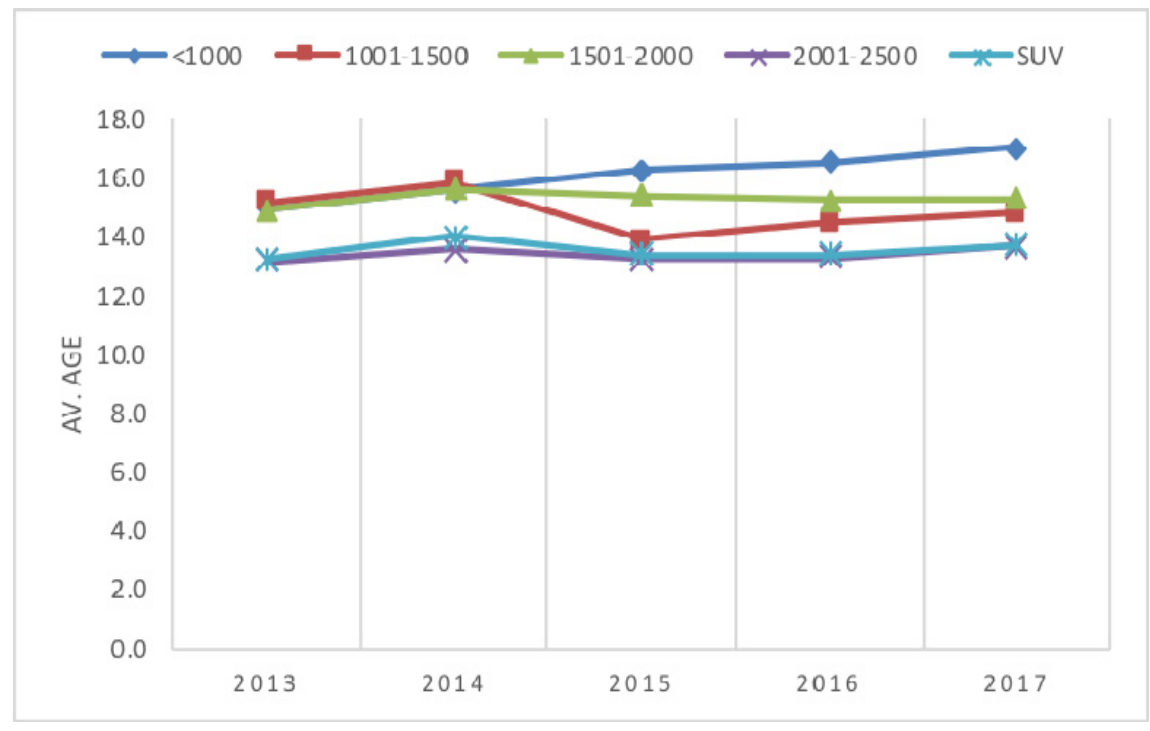

Figure 2. Age and engine capacity category, petrol fleet 


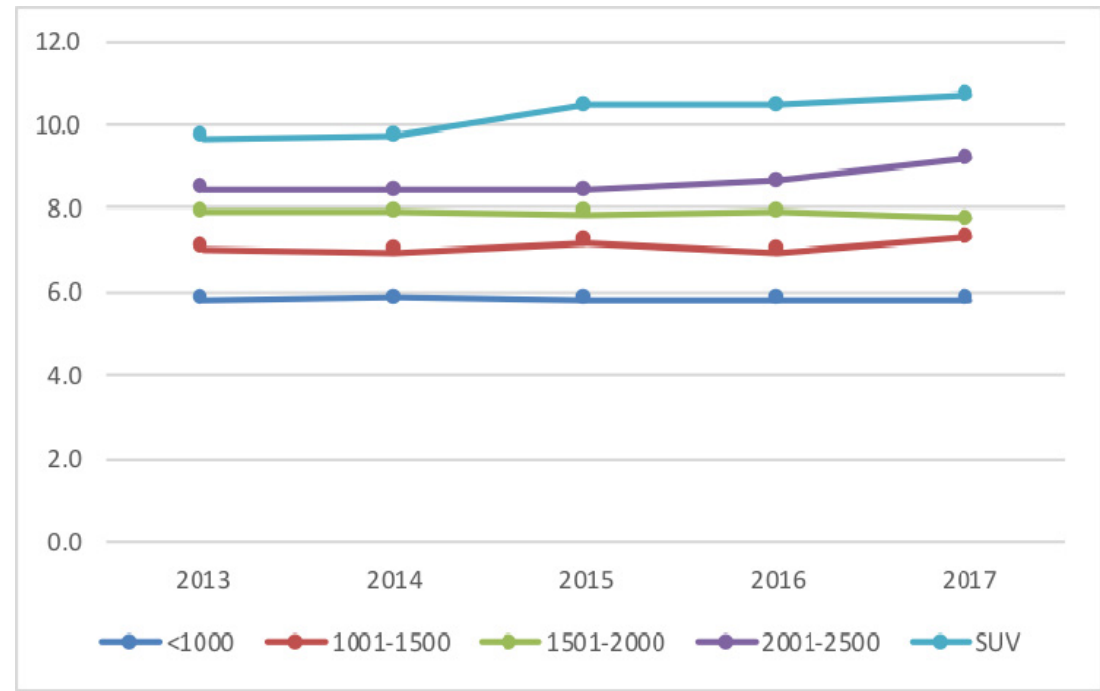

Figure 3. Engine capacity and fuel efficiency diesel fleet

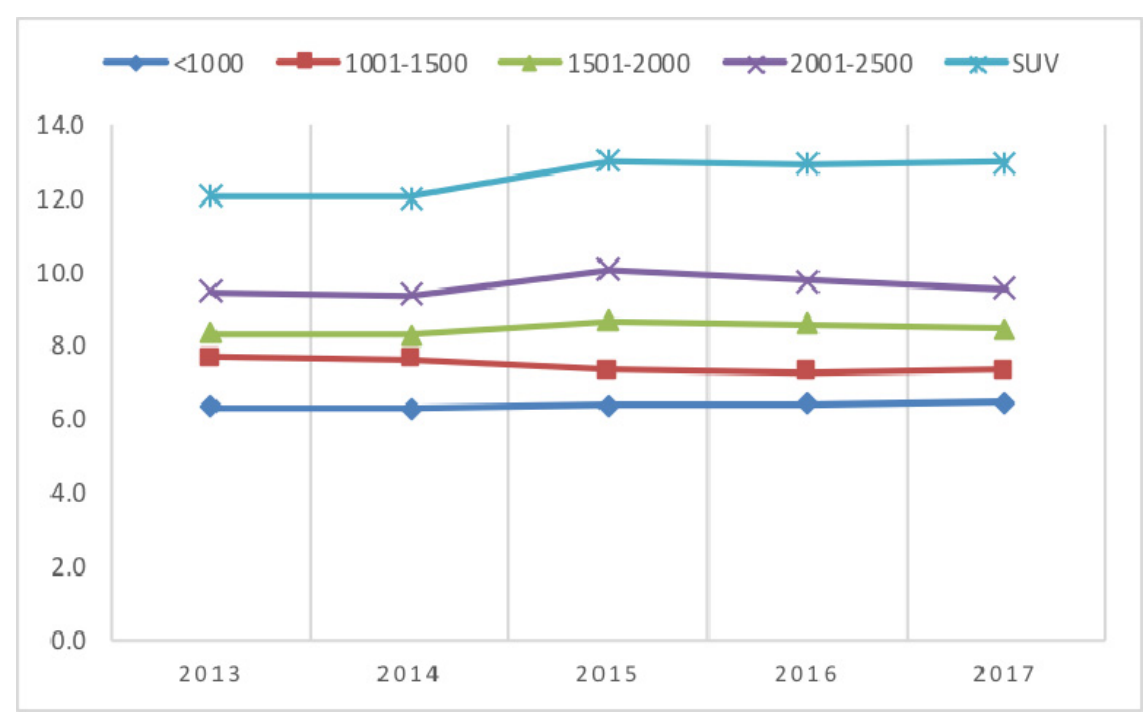

Figure 4. Engine capacity and fuel efficiency petrol fleet

Compared to the global and regional fuel efficiency targets for OECD (Organisation for Economic Co-operation and Development) and non-OECD country averages, Uganda's fleet relatively consumed more petrol. The average fuel estimate for the OECD and Non-OECD countries in addition to the global average is $9.02 \mathrm{~L} / 100 \mathrm{~km}$ in 2015 while Uganda's fuel consumption is estimated at $8.9 \mathrm{~L} / 100 \mathrm{~km}$ in 2017 . The fuel efficiency levels deviate by $52.8 \%$ from the GFEI target of $4.2 \mathrm{~L} / 100 \mathrm{~km}$ in 2030 . Uganda may reduce the fuel consumption levels by benchmarking what other countries have done in terms of fuel efficiency and pollution standards for passenger vehicles as it seems to be performing already badly.

\subsection{LDVs Fuel type, Engine Capacities and Fuel Efficiency}

The age and fuel efficiency of LDV fleet was assessed to provide insights into the implications of a regulatory policy on age of vehicles imported into the country given that they are the most widely used in Uganda. Findings show that for diesel LDV fleet, the 
average age of registered vehicles increased from 11.6-15.3 years between 2013 and 2017. Similarly, fuel efficiency increased by 1 unit, implying an increase of $10.9 \%$ of the fuel required to travel a similar distance for vehicles imported in 2017 relative to those of 2013(see Table 4). Notably, the average engine capacity was 2864.9CC in 2013 and 2920 CC in 2017 and these are branded as SUVs. The results imply that fuel efficiency (FE) increases with age.

For the Petrol fleet, the average age remained approximately 15 years between the same period but increased from 14.7 years to 14.8 years over the same period. This implies that the relatively high age of vehicles at registration is of concern to promoting fuel economy national policy, since older cars for any engine capacity and vehicle technology consume more fuel and hence emit more $\mathrm{CO}_{2}$ per kilometre. The average age has been worsening for all categories of engine capacity despite the imposition of the environmental tax by URA in 2008. This is a deviation from the global target of 4.2 .

Also the average fuel efficiency increased slightly from $8.7 \mathrm{~L} / 100 \mathrm{~km}$ to $8.9 \mathrm{~L} / 100 \mathrm{~km}$, implying a slight increase in fuel demanded of $2.3 \%$ to cover similar distance for fleet registered in 2017 relative to those registered in 2013. Overall, the average fuel efficiency of LDVs increased from $8.8 \mathrm{~L} / 100 \mathrm{~km}$ in 2013 to $9.1 \mathrm{~L} / 100 \mathrm{~km}$ in 2017 implying a $3.3 \%$ increase in the demand of fuel for vehicles imported between 2013 and 2017. Besides fuel efficiency, the average engine capacity increased relatively to 2023.5 CC (2017) from $1946.3 \mathrm{CC}$ in 2013. However, engine capacities have been declining for all categories and fuel types (see 错误!未找到引用源。). Similarly, registrations of brand-new vehicles has steadily declined in all vehicle categories, implying more used cars are being imported into the country.

From the analysis of age and engine capacities of LDV's, the results showed that on average, the age of the fleet across all categories increased, except for engine capacities ranging from 1001-1500 and 1501-2000 categories which averaged at 15 years. Significant increases were registered in vehicle registrations less than 1001CC and SUVs which increased from 15.1-17.1 and 12.6-14.5 years respectively between 2013 and 2017. The results also showed that SUVs consumed more fuel for $100 \mathrm{~km}$ under the LDV category. Fuel efficiency of vehicles in all categories except 1001-1500CC increased between 2013 and 2017(see Table 6). The worrying situation is that SUVs which are fuel guzzlers had an estimated increase in average fuel consumption of $8.4 \%$ from 2013-2017. This could be attributed to the increased demand of SUVs and relatively older versions, that do not make use of the recent technology that is cognizant of the environment.

Increases in fuel consumption may be due to there being a lack of understanding of fuel efficiency policies and their benefit. For example policies that would be used as solutions to fuel efficiency such as high fuel prices and fuel tax are used for generating government revenue in Uganda. Whereas vehicles older than eight years are hit by a 50 percent environmental tax compared to vehicles between five and eight years old that require a tax rate of 35 percent, there is still a concern of whether the differentiation in taxation will promote a reduction in fuel efficiency. There is also lack of institutional coordination and cooperation between the Energy, Environment, Transport and Finance Ministries that would serve as a deterrent to develop comprehensive fuel economy policies.

Further, there is little documentation about the current policy interventions being 


\section{Macrothink

implemented to promote fuel efficiency economy in Uganda. This is largely because there is no national vehicle fuel economy policy in place currently. Nonetheless, the non-motorized transport policy 2012, and the draft Urban Transport policy (2014), contain a number of proposals for traffic management and safety, road quality and promotion of public transport, all of which if fully implemented would contribute to the vehicle fuel efficiency, particularly for motor vehicles within the capital city and other major towns. For instance, according to the Uganda Vision- 2040, at least $80 \%$ of Uganda's freight transport will be carried by rail and the standard gauge rail will transport at least $10 \%$ of all persons for inter-urban and international trips by year 2040 (National Planning Authority (NPA), 2010). The review of documents and consultations held with stakeholders revealed that there were a few interventions directly related to fuel efficiency.

Table 4. Age and fuel efficiency of LDV fleet

\begin{tabular}{lllllll}
\hline \multirow{2}{*}{$\begin{array}{l}\text { Fuel type } \\
\text { Year }\end{array}$} & \multicolumn{2}{l}{ Diesel Fleet } & \multicolumn{3}{c}{ Petrol Fleet } \\
\hline 2013 & 11.6 & 9.2 & 2864.9 & 14.7 & 8.7 & 1946.3 \\
2014 & 12.7 & 9.2 & 2849.2 & 15.3 & 8.6 & 1947.2 \\
2015 & 13.0 & 9.8 & 2867.6 & 14.7 & 9.0 & 1976.9 \\
2016 & 14.5 & 10.0 & 2895.3 & 14.6 & 9.1 & 2040.2 \\
2017 & 15.3 & 10.2 & 2920.0 & 14.8 & 8.9 & 2023.5 \\
\hline
\end{tabular}

Source: Computations based on vehicle registration data for the period 2013-2017.

Table 5. LDV vehicle inventory by engine capacity at registration

\begin{tabular}{llllllllllllll} 
Engine Capacity & DIESEL & \multicolumn{1}{c}{ PETROL } & \multicolumn{1}{c}{ Total } \\
& $\mathbf{2 0 1 3}$ & $\mathbf{2 0 1 4}$ & $\mathbf{2 0 1 5}$ & $\mathbf{2 0 1 6}$ & $\mathbf{2 0 1 7}$ & $\mathbf{2 0 1 3}$ & $\mathbf{2 0 1 4}$ & $\mathbf{2 0 1 5}$ & $\mathbf{2 0 1 6}$ & $\mathbf{2 0 1 7}$ & \\
\hline$<1000$ & 13 & 18 & 2 & 3 & 3 & 944 & 1249 & 672 & 542 & 339 & 3785 \\
$1001-1500$ & 30 & 39 & 15 & 15 & 24 & 4242 & 5680 & 5691 & 3574 & 4214 & 23524 \\
$1501-2000$ & 248 & 429 & 222 & 230 & 178 & 16813 & 23105 & 14780 & 12877 & 12759 & 81641 \\
$2001-2500$ & 1429 & 1918 & 1135 & 688 & 548 & 2043 & 2996 & 2356 & 3219 & 3947 & 20279 \\
SUV & 3192 & 4291 & 2997 & 2973 & 2423 & 3023 & 4184 & 3466 & 3196 & 2695 & 32440 \\
Total & $\mathbf{4 9 1 2}$ & $\mathbf{6 6 9 5}$ & $\mathbf{4 3 7 1}$ & $\mathbf{3 9 0 9}$ & $\mathbf{3 1 7 6}$ & $\mathbf{2 7 0 6 5}$ & $\mathbf{3 7 2 1 4}$ & $\mathbf{2 6 9 6 5}$ & $\mathbf{2 3 4 0 8}$ & $\mathbf{2 3 9 5 4}$ & $\mathbf{1 6 1 6 6 9}$ \\
\hline
\end{tabular}

Source: Computations based on vehicle registration data for the period 2013-2017. 
Table 6. Age, Engine capacities and Fuel efficiency (Power CC) categories by year of registration

\begin{tabular}{lccccccccccc}
\hline LDV Engine capacity & 2013 & \multicolumn{3}{c}{$\mathbf{2 0 1 4}$} & \multicolumn{2}{c}{2015} & \multicolumn{2}{c}{$\mathbf{2 0 1 6}$} & \multicolumn{3}{c}{2017} \\
& \multicolumn{1}{c}{ Av age Av FE Av age Av FE Av age Av FE Av age Av FE Av age Av FE } \\
\hline$<1000$ & 15.1 & 6.3 & 15.6 & 6.3 & 16.3 & 6.4 & 16.6 & 6.4 & 17.1 & 6.4 \\
$1001-1500$ & 15.2 & 7.7 & 15.9 & 7.6 & 13.9 & 7.3 & 14.5 & 7.3 & 14.8 & 7.3 \\
$1501-2000$ & 15.0 & 8.3 & 15.7 & 8.3 & 15.5 & 8.7 & 15.3 & 8.6 & 15.4 & 8.4 \\
$2001-2500$ & 11.6 & 9.1 & 12.0 & 9.0 & 12.2 & 9.6 & 13.4 & 9.6 & 13.7 & 9.5 \\
SUV & 12.6 & 10.9 & 13.7 & 10.9 & 13.6 & 11.8 & 13.8 & 11.8 & 14.5 & 11.9 \\
Total & $\mathbf{1 4 . 2}$ & $\mathbf{8 . 8}$ & $\mathbf{1 4 . 9}$ & $\mathbf{8 . 7}$ & $\mathbf{1 4 . 5}$ & $\mathbf{9 . 1}$ & $\mathbf{1 4 . 6}$ & $\mathbf{9 . 2}$ & $\mathbf{1 4 . 9}$ & $\mathbf{9 . 1}$ \\
\hline
\end{tabular}

Source: Computations based on vehicle registration data for the period 2013-2017.

\subsection{Fleet Fuel Type, Engine Capacity and Carbon Emissions}

Findings show that on average $\mathrm{CO}_{2}$ emissions have remained high with some categories increasing relatively across fuel types. The overall $\mathrm{CO}_{2}$ emissions for diesel fleet increased from $244.2 \mathrm{gCO}_{2} / \mathrm{km}$ to $271.1 \mathrm{gCO}_{2} / \mathrm{km}$ while for petrol it increased slightly from 201.2 $\mathrm{gCO}_{2} / \mathrm{Km}$ to $207.1 \mathrm{gCO}_{2} / \mathrm{Km}$ between 2013-2017 (see Table 7). The average $\mathrm{CO}_{2}$ emission of new diesel fleet was estimated at $217.5 \mathrm{gCO}_{2} / \mathrm{km}$ in 2013 . This increased to $263.2 \mathrm{gCO}_{2} / \mathrm{Km}$ in 2017. Similarly for petrol fleet it was estimated to have declined from $252.8 \mathrm{gCO}_{2} / \mathrm{Km}$ in 2013 to $226.8 \mathrm{gCO}_{2} / \mathrm{km}$ in 2017 . The increase in $\mathrm{CO} 2$ for diesel fleet between 2013 and 2017 may be attributed to the importation of bigger vehicles (higher engine capacities) and absence of policies that would be used as solutions to transport environmental emissions such as high fuel prices and fuel tax as fuel prices and tax are used for generating government revenue in Uganda. Whereas vehicles older than eight years are hit by a 50 percent environmental tax compared to vehicles between five and eight years old that require a tax rate of 35 percent, there is still a concern of whether the differentiation in taxation will promote a reduction in carbon emissions. Even vehicles of five or eight years may produce higher carbon emissions and consume more fuel due to factors related to drivers' attitude towards the two aspects. However, findings indicated that between 2013 and 2017 , average power for diesel fleet increased from 2886.6CC to $2960.3 \mathrm{CC}$ while the average power for petrol fleet declined relatively from $2879.8 \mathrm{CC}$ in 2013 to $2567.7 \mathrm{CC}$ in 2017 which translates into reduced emissions. 
Table 7. $\mathrm{CO} 2(\mathrm{gCO} 2 / \mathrm{Km})$ emissions by engine capacity categories and Fuel type

\begin{tabular}{lllllllllll}
\hline \multirow{2}{*}{$\begin{array}{l}\text { Engine } \\
\text { capacity }\end{array}$} & \multicolumn{3}{c}{$\mathrm{CO}_{2}$ Emissions Diesel Fleet } & \multicolumn{5}{c}{$\mathrm{CO}_{2}$ Emissions Petrol Fleet } \\
\hline$<1000$ & $\mathbf{2 0 1 3}$ & $\mathbf{2 0 1 4}$ & $\mathbf{2 0 1 5}$ & $\mathbf{2 0 1 6}$ & $\mathbf{2 0 1 7}$ & $\mathbf{2 0 1 3}$ & $\mathbf{2 0 1 4}$ & $\mathbf{2 0 1 5}$ & $\mathbf{2 0 1 6}$ & $\mathbf{2 0 1 7}$ \\
$1001-1500$ & 186.0 & 155.3 & 155.1 & 155.1 & 155.1 & 146.8 & 146.2 & 147.6 & 148.7 & 149.6 \\
$1501-2000$ & 209.7 & 209.6 & 207.9 & 209.6 & 205.6 & 193.4 & 192.8 & 201.2 & 199.2 & 196.3 \\
$2001-2500$ & 224.7 & 223.1 & 223.5 & 229.1 & 243.6 & 219.5 & 218.2 & 234.1 & 227.0 & 222.2 \\
SUV & 256.4 & 257.4 & 277.1 & 277.6 & 283.0 & 280.9 & 279.4 & 302.8 & 301.2 & 301.8 \\
Total & $\mathbf{2 4 4 . 2}$ & $\mathbf{2 4 3 . 8}$ & $\mathbf{2 5 9 . 3}$ & $\mathbf{2 6 4 . 6}$ & $\mathbf{2 7 1 . 1}$ & $\mathbf{2 0 1 . 2}$ & $\mathbf{2 0 0 . 6}$ & $\mathbf{2 0 9 . 2}$ & $\mathbf{2 1 1 . 3}$ & $\mathbf{2 0 7 . 1}$ \\
\hline
\end{tabular}

Source: Computations based on vehicle registration data for the period 2013-2017.

\section{Conclusion}

The paper aimed at establishing the relationship between age, engine capacity, fuel type and fuel efficiency and carbon emissions using newly imported registered vehicle stock. The findings indicate a positive relationship between a vehicle's age, engine capacity, fuel type, vehicle category (LDV, MDV and HDV) and fuel efficiency and carbon emissions. Fuel efficiency estimates increased for the imported vehicles implying an increase in fuel consumption regardless of their age, fuel type and engine capacity. SUVs were found to be the highest fuel guzzlers compared to LDVs. While carbon emissions for both the diesel and petrol fleet increased, a slight increase was observed in the petrol fleet. Further, the average age for the engine capacity categories was worsening meaning that vehicles with older technology were still being imported into the country. A reduction in fuel consumption was observed in petrol vehicles while diesel vehicles had increased fuel consumption due to an increase in engine capacities. An improvement in fuel efficiency results in a reduction in carbon emissions and a reduction in emissions results in improvements in climate change problems.

\section{Research Implications}

The research has implications to transport system operators, academicians and policy makers. The transport policy makers will be able to devise better ways of improving efficiency of transport systems such as driver training on fuel efficiency issues and also strengthening rules on vehicle importation and clearance. Policy options available for Uganda to promote vehicle fuel efficiency include: regulatory policies, fiscal-related incentives/disincentives and traffic control measures. Regulatory policies that may be considered include encouraging importation of vehicles with up to date technologies, charging varied registration fees depending on the age of the vehicle in addition to the environmental levy and encouraging and providing more secure environments for non-motorised transport. Charging varied registration fees means that vehicles beyond eight years will be charged higher registration fees. However, implementation of policies depends on the level of technology, the level of road infrastructure and institutional capacity for enforcement of the policies. More effective policies that promote interactions between the policy makers and transport system operators 
may be developed. To academicians, the research contributes to the body of knowledge through examining the effect of age, engine capacity, vehicle category and fuel type on carbon emissions and fuel efficiency.

Whereas much of the focus is placed on policy options, attitudinal and behavioural aspects are ignored. Both an attitudinal and behavioural change of the motor vehicle operators may have an impact on fuel efficiency and gas emissions. Therefore, research examining the impact of attitudes and behavioural aspects of motorists on fuel efficiency and carbon emissions is vital. Also more research is required on the impact of vehicle technologies inherent in different vehicle models on fuel efficiency and carbon emissions. This is an area where researchers have been silent.

\section{Acknowledgements}

We acknowledge the grant funding received from The Norwegian Agency for Development Cooperation (Norad) under the NORHED project - Capacity building in Education and Research for Economic Governance in Uganda (QZA-0486-13/0017) to undertake this research.

\section{References}

Afedraru, L. (2015). From Journalist to Passion Fruit Grower. The Daily Monitor, 25.

Ahn, K., Rakha, H., Trani, A., \& Van Aerde, M. (2002). Estimating vehicle fuel consumption and emissions based on instantaneous speed and acceleration levels. Journal of Transportation Engineering, 128(2), 182-190. https://doi.org/10.1061/(ASCE)0733-947X (2002)128:2(182).

Alam, M. S., Hyde, B., Duffy, P., \& McNabola, A. (2018). Analysing the Co-Benefits of transport fleet and fuel policies in reducing PM2. 5 and $\mathrm{CO} 2$ emissions. Journal of cleaner production, 172, 623-634.

Alvarez, R., \& Weilenmann, M. (2012). Effect of low ambient temperature on fuel consumption and pollutant and $\mathrm{CO}_{2}$ emissions of hybrid electric vehicles in real-world conditions, Fuel, 97, 119-24. https://doi.org/10.1016/j.fuel.2012.01.022

Ardekani, S., \& Sumitsawan, P. (2010). Effect of pavement type on fuel consumption and emissions in city driving. The University of Texas at Arlington, Research dissertation.

Barkenbus, J. N. (2010). Eco-driving: An overlooked climate change initiative. Energy Policy, 38(2), 762-769. https://doi.org/10.1016/j.enpol.2009.10.021

Barth, M., \& Boriboonsomsin, K. (2009). Energy and emissions impacts of a freeway-based dynamic eco-driving system. Transportation Research Part D: Transport and Environment, 14(6), 400-410. https://doi.org/10.1016/j.trd.2009.01.004

Beusen, B., Broekx, S., Denys, T., Beckx, C., Degraeuwe, B., \& Gijsbers, M. (2009). Using onboard logging devices to study the longer-term impact of an eco-driving course. Transportation Research Part D: Transport and Environment, 14, 514-20. https://doi.org/10. 1016/j.trd.2009.05.009

Bishop, J. D. K., Martin, N. P. D., \& Boies, A. M. (2014). Cost-effectiveness of alternative powertrains for reduced energy use and $\mathrm{CO}_{2}$ emissions in passenger vehicles. Applied Energy, 124, 44-61. https://doi.org/10.1016/j.apenergy.2014.02.019 
Bromberg, L., Cohn, D. R., Rabinovich, A., \& Heywood, J. (2001). Emissions reductions using hydrogen from plasmatron fuel converters. International Journal of Hydrogen Energy, 26(10), 1115-1121. https://doi.org/10.1016/S0360-3199(01)00049-0

Brundell-Freij, K., \& Ericsson, E. (2005). Influence of street characteristics, driver category and car performance on urban driving patterns. Transportation Research Part D: Transport and Environment, 10(3), 213-229. https://doi.org/10.1016/j.trd.2005.01.001

Buchmann, E. J., \& Downs, C. T. (2018). Ostrich, Southern Ostrich or Common Ostrich? The 'eternal vexed question' of English bird names and name changes in southern Africa through eight editions of Roberts field guides, 1940-2016. Ostrich, 89(3), 205-210. https://doi.org/10.2989/00306525.2018.1460408

Burgess, S. C., \& Choi, J. M .J. (2003). A parametric study of the energy demands of car transportation: a case study of two competing commuter routes in the UK. Transportation Research Part D: Transport and Environment, 8(1), 21-36. https://doi.org/10.1016/S13619209(02)00016-0

Chiang, H. L., Tsai, J. H., Yao, Y. C., \& Ho, W. Y. (2008). Deterioration of gasoline vehicle emissions and effectiveness of tune-up for high-polluted vehicles. Transportation Research Part D: Transport and Environment, 13(1), 47-53. https://doi.org/10.1016/j.trd.2007.07.004

Crandall, R. W., \& Graham, J. D. (1989). The effect of fuel economy standards on automobile safety. The Journal of Law and Economics, 32(1), 97-118. https://doi.org/10.1086/467170

Crolla ,D. (2009). Automotive engineering, powertrain. Chassis system and vehicle body. 1st ed. Butterworth-Heinemann an Imprint of Elsevier.

Dardiotis, C., Martini, G., Marotta, A., \& Manfredi, U. (2013). Low-temperature cold-start gaseous emissions of late technology passenger cars. Applied Energy, 111, 468-78. https://doi.org/10.1016/j.apenergy.2013.04.093

Demirbas, A. (2003). Current advances in alternative motor fuels. Energy exploration \& exploitation, 21(5), 475-487. https://doi.org/10.1260/014459803322986295

Ericsson, E. (2001). Independent driving pattern factors and their influence on fuel-use and exhaust emission factors. Transportation Research Part D: Transport and Environment, 6(5), 325-345. https://doi.org/10.1016/S1361-9209(01)00003-7

European Environmental Agency. (2016). EEA. Monitoring of $\mathrm{CO}_{2}$ emissions from passenger cars regulation 443/2009/

European Environmental Agency. (2018). Average CO2 emissions from new cars and new vans increased in 2018.

Fingerman, K. R., Sheppard, C., \& Harris, A. (2018). California's Low Carbon Fuel Standard: Modeling financial least-cost pathways to compliance in Northwest California. Transportation Research Part D: Transport and Environment, 63, 320-332. https://doi.org/ 10.1016/j.trd.2018.06.008

Fomunung, I., Washington, S., \& Guensler, R. (1999). A statistical model for estimating oxides of nitrogen emissions from light duty motor vehicles. Transportation Research Part D: Transport and Environment, 4(5), 333-352. https://doi.org/10.1016/S1361-9209(99)00013-9

Fontaras, G., \& Dilara, P. (2012). The evolution of European passenger car characteristics 
2000-2010 and its effects on real-world $\mathrm{CO}_{2}$ emissions and $\mathrm{CO}_{2}$ reduction policy. Energy Policy, 49,719-30. https://doi.org/10.1016/j.enpol.2012.07.021

Fontaras, G., Zacharof, N. G., \& Ciuffo, B. (2017). Fuel consumption and $\mathrm{CO}_{2}$ emissions from passenger cars in Europe-Laboratory versus real-world emissions. Progress in Energy and Combustion Science, 60, 97-131. https://doi.org/10.1016/j.pecs.2016.12.004

GFEI. (2014). Cleaner, more efficient Vehicles Tool, Global Fuel Economy Initiative.

GFEI. (2015a) International comparison of light duty vehicle fuel economy: Evolution over 8 years from 2005 to 2013 Global Fuel Economy Initiative, London.

GFEI. (2015b). Fuel Economy State of the World 2016: Time for Global Action. Global Fuel Economy Initiative, London.

GFEI.(2016). Fuel Economy State of the World 2016: Time for global action, London.

Greene, D. L. (2008). Vehicles and E85 Stations Needed to Achieve Ethanol Goals. Transportation Research Record: Journal of the Transportation Research Board, 2058(1), 172-178. https://doi.org/10.3141/2058-21

Harrington, W. (1997). Fuel economy and motor vehicle emissions. Journal of environmental economics and management, 33(3), 240-252. https://doi.org/10.1006/jeem.1997.0994

Haworth, N., \& Symmons, M. (2001). Driving to reduce fuel consumption and improve road safety. Monash University Accident Research Centre.

Hertel, T. W., \& Rosch, S. D. (2010). Climate change, agriculture and poverty. The World Bank. https://doi.org/10.1596/1813-9450-5468

Hsieh, W. D., Chen, R. H., Wu, T. L., \& Lin, T. H. (2002). Engine performance and pollutant emission of an SI engine using ethanol-gasoline blended fuels. Atmospheric Environment, 36(3), 403-410. https://doi.org/10.1016/S1352-2310(01)00508-8

Hucho, W., \& Sovran, G. (1993). Aerodynamics of road vehicles. Annual review of fluid mechanics, 25(1), 485-537. https://doi.org/10.1146/annurev.fl.25.010193.002413

IEA-International Energy Agency, UIC-International Union of Railways (2013). Railway Handbook 2013, Energy Consumption and $\mathrm{CO}_{2}$ Emissions. Paris, France: ETF-Railway Technical Publications

Jimenez-Valdivia, L. M., Malpartida-Carrillo, V., Rodríguez-Cárdenas, Y. A., Dias-Da Silveira, H. L., \& Arriola-Guillén, L. E. (2019). Midpalatal suture maturation stage assessment in adolescents and young adults using cone-beam computed tomography. Progress in orthodontics, 20(1), 38-45. https://doi.org/10.1186/s40510-019-0291-z

Joumard, R., Andre, M., Laurikko, J., Le Anh, T., Geivanidis, S., \& Samaras, Z. (2006). Accuracy of exhaust emissions measurements on vehicle bench (Artemis deliverable 2).

Karlsson, A., Carlson, R \& Dolk, E. (2012). Energy use generated by traffic and pavement maintenance. Decision support for optimization of low rolling resistance.

Kirby, H. R., Hutton, B., McQuaid, R. W., Raeside, R., \& Zhang, X. (2000). Modelling the effects of transport policy levers on fuel efficiency and national fuel consumption. Transportation Research Part D: Transport and Environment, 5(4), 265-282. https://doi.org/ 10.1016/S1361-9209(99)00037-1

Kwon, T. H. (2006). The determinants of the changes in car fuel efficiency in Great Britain 
(1978-2000). Energy Policy, 34(15), 2405-2412. https://doi.org/10.1016/j.enpol.2005.04.014

Leduc, P., Dubar, B., Ranini, A., \& Monnier, G. (2003). Downsizing of gasoline engine: an efficient way to reduce $\mathrm{CO}_{2}$ emissions. Oil \& gas science and technology, 58(1), 115-127. https://doi.org/10.2516/ogst:2003008

Mathew, T. V. (2014). Fuel consumption and emission studies. Transportation Systems Engineering, 1-25.

Mock, P., German, J., Bandivadekar, A \& Riemersma, I. (2012). Discrepancies between typeapproval and "real-world" fuel consumption and $\mathrm{CO}_{2}$ values - assessment for 2001-2011 European passenger cars. International Council on Clean Transportation.

Morrow, W. R., Gallagher, K. S., Collantes, G., \& Lee, H. (2010). Analysis of policies to reduce oil consumption and greenhouse-gas emissions from the US transportation sector. Energy Policy, 38(3), 1305-1320. https://doi.org/10.1016/j.enpol.2009.11.006

Musti, S., \& Kockelman, K. M. (2011). Evolution of the household vehicle fleet: Anticipating fleet composition, PHEV adoption and GHG emissions in Austin, Texas. Transportation Research Part A: Policy and Practice, 45(8), 707-720. https://doi.org/10.1016/j.tra.2011.04. 011

Mutenyo, J., Banga, M., Matovu, F., Kimera, D., \& Lawerence, K. (2015). Baseline survey on Uganda's national average automotive fuel economy, Global Fuel Economy Initiative.

Niculescu, R., Clenci, A., \& Iorga-Siman, V. (2019). Review on the use of diesel-Biodiesel-Alcohol blends in compression ignition engines. Energies, 12(7), 1194. https://doi.org/10.3390/en12071194

Ogden, J., Jaffe, A. M., Scheitrum, D., McDonald, Z., \& Miller, M. (2018). Natural gas as a bridge to hydrogen transportation fuel: Insights from the literature. Energy policy, 115, 317-329. https://doi.org/10.1016/j.enpol.2017.12.049

Pagerit, S., Sharer, P., \& Rousseau, A. (2006). Fuel economy sensitivity to vehicle mass for advanced vehicle powertrains. https://doi.org/10.4271/2006-01-0665

Parker, R. W., Blanchard, J. L., Gardner, C., Green, B. S., Hartmann, K., Tyedmers, P. H., \&

Popp, M., Van de Velde, L., Vickery, G., Van Huylenbroeck, G., Verbeke, W., \& Dixon, B. (2009). Determinants of consumer interest in fuel economy: Lessons for strengthening the conservation argument. Biomass and Bioenergy, 33(5), 768-778. https://doi.org/10.1016/ j.biombioe.2008.12.007

Rajesh, A. V., Sundaram, C. M., Sivaganesan, V., Nagarajan, B., \& Harikishore, S. (2019). Emission reduction techniques in CI engine with catalytic converter. Materials Today: Proceedings.

Rakha, H., \& Ding, Y. (2003). Impact of stops on vehicle fuel consumption and emissions. Journal of Transportation Engineering, 129(1), 23-32. https://doi.org/10.1061/(ASCE)0733947X(2003)129:1(23)

Salamon, C., McAllister, M., Robinson, R., Richardson, S., Martinez-Botas, R., Romagnoli, A., \& Turner, J. (2012). Improving fuel economy by 35\% through combined turbo and supercharging on a spark ignition engine. Paper presented at 21st Aachen Colloquium Automobile and Engine Technology, 2012, Aachen, Germany, UK United Kingdom. 
Samaras, C., \& Meisterling, K. (2008). Life cycle assessment of greenhouse gas emissions from plug-in hybrid vehicles: implications for policy. Environ. Sci. Technol, 42, 3170-3176. https://doi.org/10.1021/es702178s

Sanchez, P. A. (2000). Linking climate change research with food security and poverty reduction in the tropics. Agriculture, Ecosystems \& Environment, 82(1-3), 371-383. https://doi.org/10.1016/S0167-8809(00)00238-3

Shaw, C., Hales, S., Edwards, R., Howden-Chapman, P., \& Stanley, J. (2018). What can fuel price increases tell us about the air pollution health co-benefits of a carbon price? Journal of Transport \& Health, 8, 81-90. https://doi.org/10.1016/j.jth.2017.11.002

Smit, R., \& Brown, A. L. (2008). Do air pollution emissions and fuel consumption models for roadways include the effects of congestion in the roadway traffic flow. Environmental Modelling Software, 23, 1262-1270. https://doi.org/10.1016/j.envsoft.2008.03.001

Song, X., Zhang, Q., Sekimoto, Y., Horanont, T., Ueyama, S., \& Shibasaki, R. (2013). Modeling and probabilistic reasoning of population evacuation during large-scale disaster. In Proceedings of the 19th ACM SIGKDD international conference on Knowledge discovery and data mining (pp. 1231-1239). ACM. https://doi.org/10.1145/2487575.2488189

Spalding, S. (2018). RACQ congested roads report. RACQ Vehicle Technology Department, Sterner, T. (2007). Fuel taxes: An important instrument for climate policy. Energy policy, 35(6), 3194-3202. https://doi.org/10.1016/j.enpol.2006.10.025

Tong, H. Y., Hung, W. T., \& Cheung, C. S. (2000). On-road motor vehicle emissions and fuel consumption in urban driving conditions. Journal of the Air \& Waste Management Association, 50(4), 543-554. https://doi.org/10.1080/10473289.2000.10464041

Van Mierlo, J., Maggetto, G., Van de Burgwal, E., \& Gense, R. (2004). Driving style and traffic measures-influence on vehicle emissions and fuel consumption. Proceedings of the Institution of Mechanical Engineers, Part D: Journal of Automobile Engineering, 218(1), 43-50. https://doi.org/10.1243/095440704322829155

Wang, H., McGlinchy, I., Badger, S., \& Wheaton, S. (2015, September). Real-world fuel efficiency of light vehicles in New Zealand. In Australasian Transport Research Forum (pp. 1-13).

Weilenmann, M. F., Alvarez, R., \& Keller, M. (2010). Fuel consumption and $\mathrm{CO}_{2} /$ pollutant emissions of mobile air conditioning at fleet level-new data and model comparison. Environmental science \& technology, 44(13), 5277-5282. https://doi.org/10.1021/es903654t

Wohlecker, R., Johannaber, M., \& Espig, M. (2007). Determination of weight elasticity of fuel economy for ice, hybrid and fuel cell vehicles, Environmental Science and Technology, https://doi.org/10.4271/2007-01-0343

Wright, L. (2004). The limits of technology: achieving transport efficiency in developing nations, in GTZ (2004) Transport in Developing Countries: Renewable Energy or Energy Reduction? Reader prepared for the Side Event at the Renewables 2004 Conference, ed. N. Sieber (Eschborn: GTZ).

Ziraba, A., \& Okolo, C. (2018). The Impact of Information Technology (IT) Policies and Strategies to Organization's Competitive Advantage/. 


\section{Macrothink}

\section{Copyright Disclaimer}

Copyright for this article is retained by the author(s), with first publication rights granted to the journal.

This is an open-access article distributed under the terms and conditions of the Creative Commons Attribution license (http://creativecommons.org/licenses/by/3.0/). 